\title{
Absorption mechanisms of $\mathrm{Cu}^{2+}$ on a biogenic bixbyite-like $\mathrm{Mn}_{2} \mathrm{O}_{3}$ produced by Bacillus CUA isolated from soil
}

\author{
Zhijun Zhang ${ }^{1}$, Jing Lai ${ }^{2}$, Hui Yin ${ }^{1}$, Xionghan Feng ${ }^{1}$, Wenfeng $\operatorname{Tan}^{1}$ and Fan Liu ${ }^{1 *}$
}

\begin{abstract}
Background: Although most reported biogenic Mn oxides are hexagonal birnessites, other types of biogenic $\mathrm{Mn}$ oxides also commonly occur in the environment. However, sorption characteristics and underlying mechanisms of the adsorption of heavy-metal ions on these biogenic Mn oxides are still rarely addressed. In this study, the sorption mechanisms of $\mathrm{Cu}(\mathrm{II})$ on a low valence biogenic $\mathrm{Mn}$ oxide, poorly crystallized bixbyite-like $\mathrm{Mn}_{2} \mathrm{O}_{3}\left(\mathrm{a}-\mathrm{Mn}_{2} \mathrm{O}_{3}\right)$, were investigated.

Results: The maximum adsorption capacity of $\mathrm{Cu}(\mathrm{II})$ onto this biogenic Mn oxide at $\mathrm{pH} 6.00$ was $796 \mathrm{mmol} / \mathrm{kg}$ ( $0.45 \mathrm{~mol} \mathrm{Cu} \mathrm{mol}^{-1} \mathrm{Mn}$ ). The complex structure of adsorbed $\mathrm{Cu}(\mathrm{II})$ was constrained using Cu extended X-ray absorption fine structure (EXAFS) analysis, combined with structural parameters of the biogenic Mn oxide with alternately arranged regular and distorted $\mathrm{MnO}_{6}$ octahedra obtained through multiple-FEFF fitting of Mn EXAFS data. The sorbed $\mathrm{Cu}(\mathrm{II})$ was found to coordinate with the biogenic Mn oxide particle edges as inner-sphere complexes. At a relatively low $\mathrm{Cu}^{2+}$ loading (233 mmol/kg, pH 6.00), Cu(II) adsorbed onto the biogenic Mn oxide with two types of coordinated complexes, i.e., (1) coordinated with one regular/distorted $\mathrm{MnO}_{6}$ octahedron as a monodentate-mononuclear complex and (2) with two adjacent $\mathrm{MnO}_{6}$ octahedra as a bidentate-binuclear complex. While, at a relatively high $\mathrm{Cu}^{2+}$ loading $(787 \mathrm{mmol} / \mathrm{kg}$, $\mathrm{pH}$ 6.00), only one type of coordinated complex was constrained, the adsorbed Cu(II) coordinated with one regular/ distorted $\mathrm{MnO}_{6}$ octahedron as a monodentate-mononuclear complex.
\end{abstract}

Conclusions: This research extends further insight into the bacterial $\mathrm{Mn}(\mathrm{II})$ oxidation in the environment and serves as a good reference for understanding the interactions between metal ions and biogenic low valence Mn oxides, which are still poorly explored either theoretically or practically.

Keywords: Biogenic Mn oxide, Mn-oxidizing bacteria, Bixbyite, XAFS, $\mathrm{Cu}^{2+}$ adsorption

\section{Background}

Copper is one of the most ancient metals of human civilization, and a trace metal in most natural environments, posing no serious threat to biota and vegetation at its background levels. However, it often poses a threat to the environment in areas with elevated levels of copper as a result of contamination from, for example, mining of copper ore minerals, untreated industrial waste waters and its widespread use in agriculture, chemical and electronics industry [1-4]. Apart from organic

\footnotetext{
*Correspondence: liufan@mail.hzau.edu.cn

'Key Laboratory of Arable Land Conservation (Middle and Lower Reaches of Yangtse River), Ministry of Agriculture, College of Resources and Environment, Huazhong Agricultural University, Wuhan 430070, China

Full list of author information is available at the end of the article
}

matter [5, 6] and clay minerals [7], the chemical speciation and mobility of $\mathrm{Cu}(\mathrm{II})$ are linked in part to $\mathrm{Mn}$ oxides in soils and sediments [8-11]. Mn oxides are environmentally ubiquitous with multiple Mn oxidation states and an important source of reactive mineral surfaces in the environment. They usually exist as fine granular, spherical or film-like particles distributed in soils and sediments. As natural highly active sorbents and oxidants, $\mathrm{Mn}$ oxides widely participate in a variety of adsorption and/or redox reactions [12-14]. These reactions control the concentration, speciation, behavior and bioavailability of many heavy-metal ions and organic pollutants in the environment.

The formation of Mn oxides in the environment is generally considered to be closely related to the microbial 
activity. Up to now, microbially mediated $\mathrm{Mn}$ (II) oxidation processes have been studied mainly using three phylogenetically different bacteria: a marine Bacillus sp. Strain G-1, Leptothrix discophora strains SS-1 and SP-6, and Pseudomonas putida strains MnB1 and GB-1 [15-20] and a variety of fungi [13, 21-24]. Accordingly, our knowledge of the adsorption and oxidation of metal cations by biogenic Mn oxides and the transformation of biogenic Mn oxides into other Mn oxide minerals is mainly based on the $\mathrm{Mn}$ oxides produced by these microorganisms [12, 25-28]. However, the primary products of $\mathrm{Mn}$ (II) oxidation by the aforementioned microorganisms (bacteria and fungi) are exclusively nanoparticulate, poorly-crystalline hexagonal birnessites with the presence of Mn mainly as Mn(IV). Considering the diverse mechanisms of biooxidation of $\mathrm{Mn}(\mathrm{II})[20,29]$, other types of biogenic Mn oxides could also be produced microbially in the environment. Hosseinkhani and Emtiati [30] first reported a gramnegative Acinetobacter sp. strain obtained from ocean water, the $\mathrm{Mn}(\mathrm{II})$-oxidizing product of which was a bixbyite-like $\mathrm{Mn}_{2} \mathrm{O}_{3}$. Then, Zhang et al. [31] reported a Bacillus CUA isolated from soil, the $\mathrm{Mn}$ (II) oxidation product of which is also poorly crystallized bixbyitelike $\mathrm{Mn}_{2} \mathrm{O}_{3}\left(\alpha-\mathrm{Mn}_{2} \mathrm{O}_{3}\right)$, a low valence of biogenic $\mathrm{Mn}$ oxides. However, compared to high valence biogenic Mn oxides (e.g., hexagonal birnessites), low valence biogenic Mn-oxides and especially their properties have been rarely reported, despite a plethora of studies on non-biogenic low valence Mn oxides. Webb et al. [32] suggested that $\mathrm{Mn}(\mathrm{III})$ is formed as an intermediate during the oxidation of $\mathrm{Mn}(\mathrm{II})$ by bacteria and can serve as both oxidant and reductant in one-electrontransfer reactions with other redox species in the biogeochemical processes. Therefore, the knowledge of formation, properties and surface reactivity of low valence biogenic Mn oxides could contribute to a new understanding of the biogeochemistry of Mn-oxides with various $\mathrm{Mn}$ valence states and the relevant elements (e.g., $\mathrm{Cu}(\mathrm{II}))$.

The sorption mechanisms of $\mathrm{Cu}$ (II) adsorbed to $\mathrm{Mn}$ oxides also has been extensively investigated $[8,11,33-$ 39]. Manceau et al. [35] claimed that the adsorbed $\mathrm{Cu}(\mathrm{II})$ on birnessite was six-fold coordination with four oxygen atoms at $1.96 \AA$ and two at $2.23 \AA$, while, Sherman and Peacock [36] maintained that the adsorbed $\mathrm{Cu}(\mathrm{II})$ on birnessite was four-fold coordination. However, they are in agreement that the adsorbed $\mathrm{Cu}(\mathrm{II})$ coordinated with three surface oxygen atoms at vacancy sites of birnessite, forming a triple-corner-sharing complex with a $\mathrm{Cu}-\mathrm{Mn}$ interatomic distance of 3.39-3.43 $\AA$ [35-37]. In addition, in aqueous solution, $\mathrm{Cu}(\mathrm{II})$ was reported to prefer a fivefold elongated square pyramidal coordination that is likely to be competitive with six-fold distorted octahedral coordination [40-42]. Sherman and Peacock [36] proposed that some $\mathrm{Cu}(\mathrm{II})$ was adsorbed in $\mathrm{Cu}$-incorporation
(Cu-INC) mode at a high $\mathrm{pH}$ value $(\mathrm{pH} \approx 8.0)$, based on the appearance of a peak near $2.9 \AA$ in the Fouriertransformed EXAFS spectrum for $\delta-\mathrm{MnO}_{2}$ sample with a loading of $0.068 \mathrm{~mol} \mathrm{Cu} \mathrm{mol}^{-1} \mathrm{Mn}$. However, in a density functional theory (DFT) study, Kwon et al. [39] argued that the incorporation of $\mathrm{Cu}$ into a vacancy site strongly inhibits the Jahn-Teller distortion of $\mathrm{Cu}$, destabilizing the $\mathrm{Cu}$-INC species relative to $\mathrm{Cu}$-TCS species at any $\mathrm{pH}$ value. More recently, Peña et al. [11] showed that $\mathrm{Cu}(\mathrm{II})$ was dominantly adsorbed at particle edges of $\delta-\mathrm{MnO}_{2}$ as dimers or polynuclear surface species with a surface loading of 0.01 to $0.26 \mathrm{~mol} \mathrm{Cu} \mathrm{mol}^{-1} \mathrm{Mn}$.

However, previous studies on $\mathrm{Cu}(\mathrm{II})$ sorption onto $\mathrm{Mn}$ oxides are mainly focused on chemically synthesized layered $\mathrm{Mn}$ oxides, including some high-valence biogenic hexagonal birnessite. There are no reports about $\mathrm{Cu}(\mathrm{II})$ sorption onto low-valence biogenic Mn oxides and the issue of how the adsorbed $\mathrm{Cu}$ (II) coordinates with the Mn oxides is rarely addressed. Here, a low-valence biogenic $\mathrm{Mn}$ oxide was prepared, and the coordination mechanisms for the sorption of $\mathrm{Cu}(\mathrm{II})$, as a model of heavy metals, onto the biogenic Mn oxide were investigated using X-ray absorption spectroscopy (XAS).

\section{Results and discussion}

\section{Sorption of $\mathrm{Cu}$ (II) onto the biogenic Mn oxide}

Adsorption isotherm of $\mathrm{Cu}$ (II) on biogenic $\mathrm{Mn}$ oxide at pH6.0 is presented in Fig. 1. At the given pH, the final adsorbed amount $(\mathrm{mmol} / \mathrm{kg})$ increased with increasing initial $\mathrm{Cu}^{2+}$ concentration. The data were fitted to a Langmuir model with a correlation coefficient of $R^{2}=0.9904$, indicating an adequate fit of the equation to the data. The maximum adsorption capacity was $796 \mathrm{mmol} / \mathrm{kg}(0.45 \mathrm{~mol} \mathrm{Cu}$ $\left.\mathrm{mol}^{-1} \mathrm{Mn}\right)$. Therefore, the biogenic $\mathrm{Mn}$ oxide $\left(\alpha-\mathrm{Mn}_{2} \mathrm{O}_{3}\right)$ could also be a promising adsorbent for eliminating $\mathrm{Cu}(\mathrm{II})$ from soil and water environments. Two sorption samples, pH6.0-Cu0.4 and pH6.0-Cu4.0, as indicated by their initial

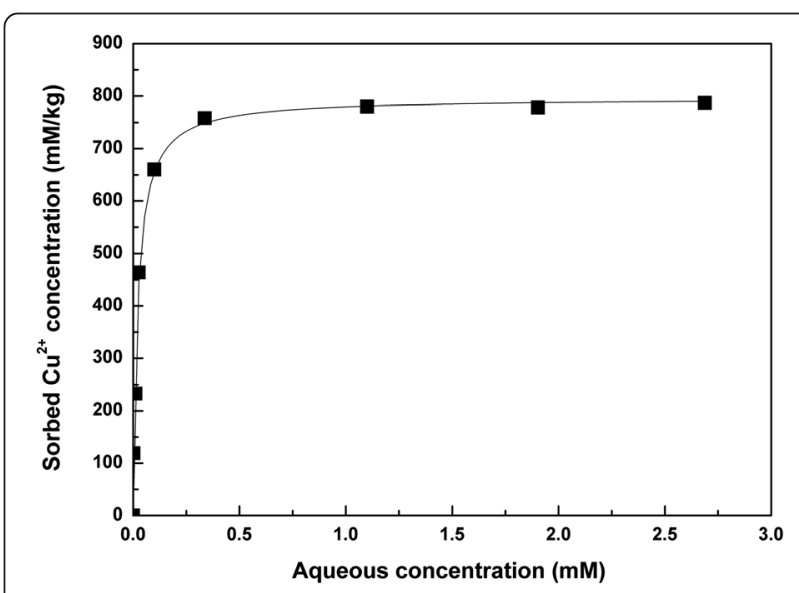

Fig. 1 Sorption isotherm of $\mathrm{Cu}^{2+}$ on biogenic $\mathrm{Mn}$ oxide at $25^{\circ} \mathrm{C}$ 
$\mathrm{pH}$ and $\mathrm{Cu}^{2+}$ concentrations (mM), were used to collect EXAFS spectra. The adsorption densities of the two samples were $233 \mathrm{mmol} / \mathrm{kg}\left(0.13 \mathrm{~mol} \mathrm{Cu} \mathrm{mol}{ }^{-1} \mathrm{Mn}\right)$ for pH6.0-Cu0.4 and $787 \mathrm{mmol} / \mathrm{kg}\left(0.44 \mathrm{~mol} \mathrm{Cu} \mathrm{mol}^{-1} \mathrm{Mn}\right)$ for $\mathrm{pH} 6.0-\mathrm{Cu} 4.0$, respectively.

\section{XAS analysis of sorbed $\mathrm{Cu}$ (II)}

Figure 2 shows $\mathrm{X}$-ray absorption near-edge structure (XANES) spectra and second derivatives of the XANES spectra of the sorption samples and some reference compounds. The two sorption samples have similar Xray absorption edges characteristic of divalent $\mathrm{Cu}(\mathrm{II})$ aqueous solution (Fig. 2a), indicating that the oxidation state of $\mathrm{Cu}$ on the surface of biogenic $\mathrm{Mn}$ oxide (Bixbyite) remains unchanged. In general, the sorbed $\mathrm{Cu}$ prefers to bind with $\mathrm{Mn}$ oxides, for example, birnessite, with three mechanisms: inner-sphere surface at cation vacancy sites and/or particle edges, incorporation into the $\mathrm{MnO}_{2}$ sheet and $\mathrm{Cu}$ polymerization or precipitation [11]. The two sorption samples differ from $\mathrm{Cu}(\mathrm{OH})_{2}$ not only in the shape and position of the XANES spectra, but also in second derivative (Fig. 2b) and EXAFS (Fig. 3), thereby eliminating the possibility of polymerization or precipitation. In tetrahedral coordination, the pre-edge feature in $\mathrm{Cu}$ K-edge XANES should show greater intensity and be shifted towards slightly lower energies [11, 43, 44], which meant that the sorbed $\mathrm{Cu}(\mathrm{II})$ was not in tetrahedral coordination. The second derivative of copper acetate monohydrate, a model compound with isolated dimeric $\mathrm{Cu}$ units, was used to determine whether dimeric $\mathrm{Cu}$ units were present in sorbed $\mathrm{Cu}(\mathrm{II})$ [45]. Here, the two sorption samples have second derivative differ with copper acetate monohydrate, which means no dimeric $\mathrm{Cu}$ unit exist in the sorbed $\mathrm{Cu}(\mathrm{II})$ on the surface of biogenic Mn oxides.
Figure 3 shows EXAFS and Fourier transforms (FT) of the sorption samples and those of reference compounds. Generally, the $d^{9}$ electronic configuration of $\mathrm{Cu}$ (II) leads to the Jahn-Teller distortion of the first coordination shell and this structure distortion leads to two distinct $\mathrm{Cu}-\mathrm{O}$ shell subshells, where the equatorial sub-shell dominates the EXAFS signal, but no reliable coordination numbers and distances of axial sub-shell could be fitted due to the anisotropic disorder [11, 45, 46]. Thus, we fit the first $\mathrm{Cu}-\mathrm{O}$ shell EXAFS spectra of $\mathrm{Cu}^{2+}$ (aq) with coordination number fixed at 4 and got the amplitude reduction factor $\left(S_{0}^{2}=0.96\right)$. Then, the other EXAFS spectra were fitted with $\mathrm{S}_{0}^{2}$ set at 0.96 , and the fitting results are listed in Table 1 . It shows that the main EXAFS contributions of the reference compounds are from oxygen atoms at approximately $\sim 1.95 \AA$, with coordination number close to 4 of this first $\mathrm{Cu}-\mathrm{O}$ shell, which agrees well with several previous reports $[11,36$, 45]. Additionally, all of the $\mathrm{Cu}-\mathrm{O}$ shells with a low Debye-Waller factor (DWF, 0.005-0.007 $\AA^{2}$ ), indicates a low local structural disorder and these $\mathrm{Cu}-\mathrm{O}$ bonds are the typical equatorial bonds of the distorted $\mathrm{Cu}$ polyhedron. Manceua et al. [35] obtained an improved fit by 4 equatorial oxygen atoms at $1.96 \AA$ and two axial oxygen atoms at $2.23 \AA$, with a much larger DWF, as expected for $\mathrm{Cu}$ in a Jahn-Teller distorted environment. We cannot confirm whether $\mathrm{Cu}$ has one or two axial ligands in our sorption samples, due to no obvious improvement with the addition of one or two axial oxygen atoms. However, in principle, both the results are reasonable, because $\mathrm{Cu}$ in aqueous solution prefers a five-fold coordination that is likely to be competitive with a six-fold distorted octahedral coordination [36, 40-42].
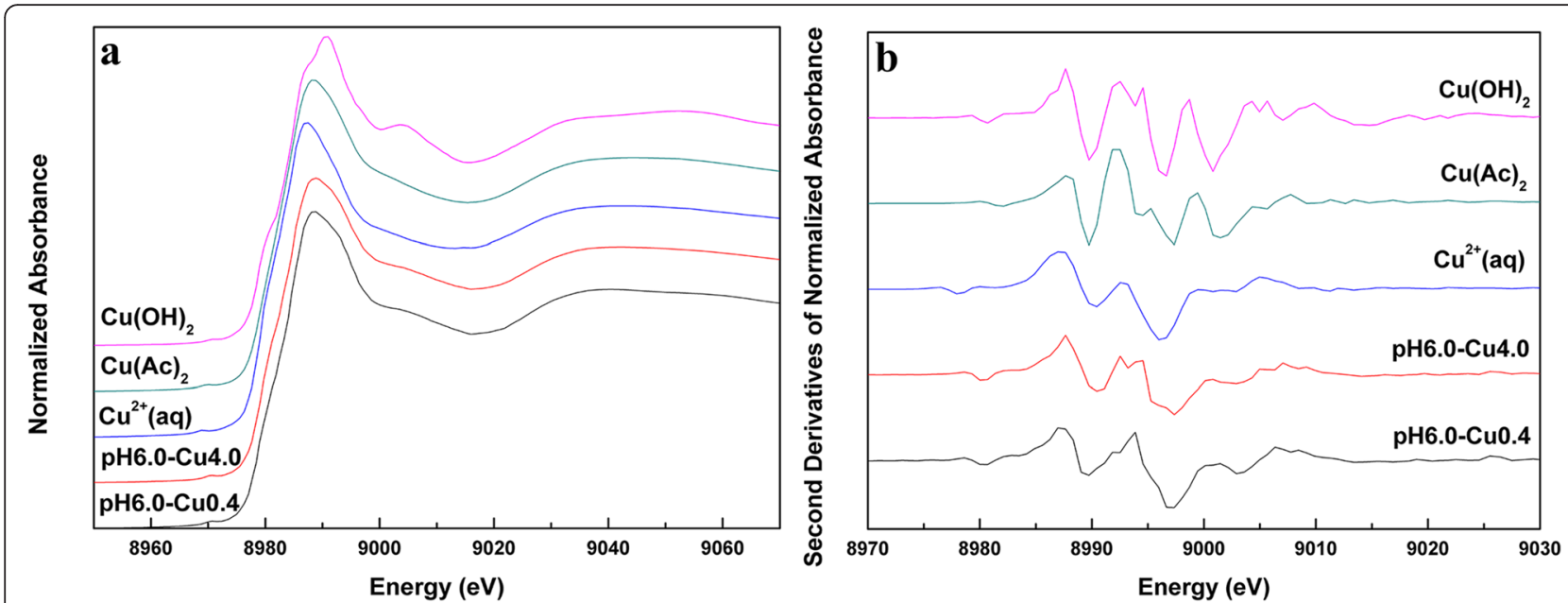

Fig. 2 Normalized X-ray absorption edges and second derivatives of XANES of all samples and the reference compounds (a) normalized X-ray absorption edges of sorption samples and some reference compounds. $\mathbf{b}$ Second derivatives of XANES features of sorption samples and the reference compounds 

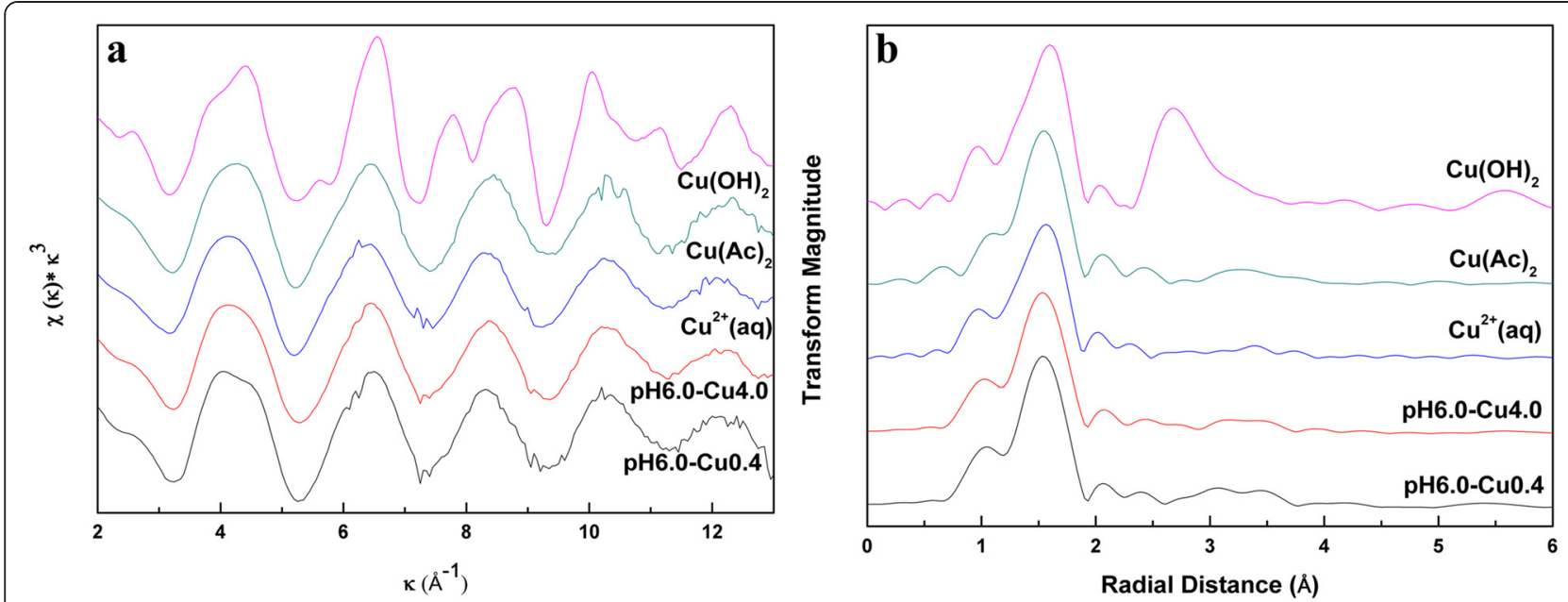

Fig. 3 EXAFS results of the two samples with sorbed $\mathrm{Cu}(\mathrm{II})$ and reference compounds (a) K space spectra; (b) RSF spectra

For the higher shell of the sorption samples, there are two main characteristic peaks (Fig. 4b), peak A ( 3.07 $\AA$, phase shift uncorrected) of pH6.0-Cu0.4, peak B $(\sim 3.14 \AA)$ of $\mathrm{pH} 6.0-\mathrm{Cu} 4.0$ and peak $\mathrm{C}(\sim 3.44 \AA)$ of the two samples. The final fitting of the raw data showed that the best fit is with one shell of oxygen at about $1.95 \AA$, one shell of $\mathrm{Mn}$ at about $3.40 \AA$, and a $\mathrm{Cu}-\mathrm{O}_{\text {eq }}-\mathrm{O}_{\text {eq }}$ multiple scattering path at about $3.90 \AA$, which is approximately twice the distance of the $\mathrm{Cu}-\mathrm{O}_{\text {eq }}$ shell $(1.95 \AA)$ [45]. The fitting results are given in Fig. 4 and Table 1.

Table 1 shows that the $\mathrm{Cu}-\mathrm{Mn}$ distance of the sample pH6.0-Cu0.4 is $3.37 \AA$ with a coordination number of $1.7(0.3)$ and that of the sample pH6.0-Cu4.0 is $3.44 \AA$ with a coordination number of $0.7(0.3)$. Sherman and Peacock [36] showed that the $\mathrm{Cu}-\mathrm{Mn}$ interatomic distance of sobred $\mathrm{Cu}$ incorporation into the $\mathrm{MnO}_{2}$ sheet

Table 1 Fitting results of the EXAFS spectra of $\mathrm{Cu}^{2+}$ sorbed on biogenic manganese oxide

\begin{tabular}{|c|c|c|c|c|c|c|}
\hline \multirow[t]{2}{*}{ Sample } & \multicolumn{3}{|l|}{$\mathrm{Cu}-\mathrm{O}$} & \multicolumn{3}{|l|}{$\mathrm{Cu}-\mathrm{Mn}$} \\
\hline & $\overline{R(\AA)^{a}}$ & $C N^{b}$ & $\sigma^{2}\left(\AA^{2}\right)^{c}$ & $R(\AA \AA)^{a}$ & $\mathrm{CN}^{\mathrm{b}}$ & $\sigma^{2}\left(\AA^{2}\right)^{c}$ \\
\hline \multirow[t]{2}{*}{$\mathrm{Cu}^{2+}(\mathrm{aq})$} & 1.953 & $4.0^{d}$ & 0.007 & - & - & - \\
\hline & $(0.001)$ & & $(0.001)$ & & & \\
\hline \multirow[t]{2}{*}{$\mathrm{Cu}(\mathrm{OH})_{2}$} & 1.948 & 4.1 & 0.005 & - & - & - \\
\hline & $(0.001)$ & $(0.3)$ & $(0.001)$ & & & \\
\hline \multirow[t]{2}{*}{$\mathrm{Cu}(\mathrm{Ac})_{2}$} & 1.946 & 4.0 & 0.005 & & & \\
\hline & $(0.001)$ & $(0.2)$ & $(0.001)$ & & & \\
\hline \multirow[t]{2}{*}{ pH6.0-Cu0.4 } & 1.945 & 4.2 & 0.006 & 3.371 & 1.7 & 0.017 \\
\hline & $(0.001)$ & $(0.3)$ & $(0.001)$ & $(0.001)$ & $(0.3)$ & $(0.009)$ \\
\hline \multirow[t]{2}{*}{ pH6.0-Cu4.0 } & 1.944 & 4.0 & 0.006 & 3.440 & 0.7 & 0.019 \\
\hline & $(0.001)$ & $(0.1)$ & $(0.001)$ & $(0.001)$ & $(0.3)$ & $(0.010)$ \\
\hline
\end{tabular}

anteratomic distance

${ }^{\mathrm{b}}$ Coordination number

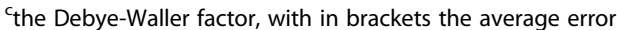

${ }^{\mathrm{d}}$ Number fixed during fit was in the range of $2.81-2.94 \AA$. In a density functional theory study, Kown et al. [39] showed that the theoretical values of $\mathrm{Cu}-\mathrm{Mn}$ distance in incorporation mode are $2.84 \AA, 2.95 \AA$ and $2.98 \AA$. Though the biogenic $\mathrm{Mn}$ oxide (Bixbyite) in this study differs in structure with birnessite, the $\mathrm{Cu}-\mathrm{Mn}$ distance $(3.37 \AA$ and $3.44 \AA)$ in the two sorption samples should be unlikely in incorporation mode. Thus, we deny the possibility of $\mathrm{Cu}$ incorporation into the biogenic $\mathrm{Mn}$ oxide in our study. In birnessite, the adsorption $\mathrm{Cu}(\mathrm{II})$ at cation vacancy sites involves the coordination of the copper to the three surface oxygen atoms surrounding the vacancy site, thus forming a triple-corner-sharing (TCS) complex [11, 35, 47]. The $\mathrm{Cu}-\mathrm{Mn}$ interatomic distances of $\mathrm{Cu}-\mathrm{TCS}$ complexes in birnessite were inferred in the range of 3.39$3.43 \AA$ with a $\mathrm{Cu}-\mathrm{Mn}$ shell coordination number of 3 [35-37]. Based on the $\mathrm{Cu}-\mathrm{Mn}$ distance, the sorbed $\mathrm{Cu}(\mathrm{II})$ on the two samples could be in $\mathrm{Cu}$-TCS complexes, but the coordination numbers of the two sorption samples are far less than 3. Additionally, there is no report of cation vacancy site in the structure of bixbyite [31]. Therefore, the sorbed $\mathrm{Cu}(\mathrm{II})$ on the two samples are unlikely in $\mathrm{Cu}$-TCS complexes. Based on the above analysis, the most possible way of sorbed $\mathrm{Cu}$ (II) on the biogenic $\mathrm{Mn}$ oxide is coordinated with the particle edges as inner-sphere surface complexes. To find out the specific ways in which the sorbed $\mathrm{Cu}(\mathrm{II})$ coordinated with the $\mathrm{MnO}_{6}$ octahedra, we used the EXAFS analysis results of our samples and the polyhedral approach for further investigation.

\section{Constraints on the structure of $\mathrm{Cu}^{2+}$ complexes on the low valence biogenic $\mathrm{Mn}$ oxide}

We cannot confirm whether $\mathrm{Cu}$ has one or two axial ligands in our sorption samples, but, in principle, both the results are reasonable [11,39], because the five-fold- 

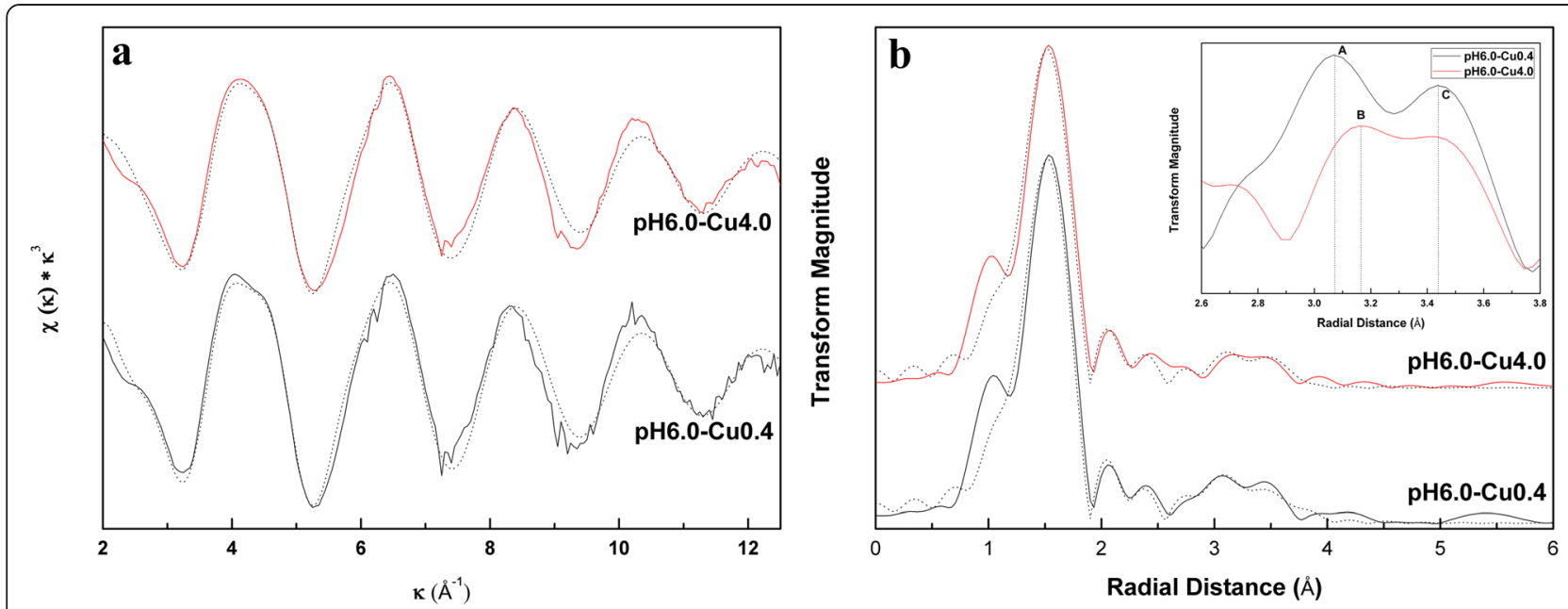

Fig. 4 EXAFS fitting results of the two samples with sorbed $\mathrm{Cu}(\mathrm{II})(\mathbf{a}) \mathrm{K}$ space spectra; (b) RSF spectra; inset: RSFs of the samples in the R-range of 2.6-3.8 A. (EXAFS data: solid line; model fitting: dotted line)

coordinate $\mathrm{Cu}$ complex showed one very long axial $\mathrm{Cu}-\mathrm{O}$ distance of $\mathrm{Cu}$ octahedron, such that the $\mathrm{Cu}$ coordination appeared to be essentially five-fold [39]. Kwon et al. [39] also showed in their DFT calculation that the structural parameters of the five-fold-coordinate complex were not distinguishable from the corresponding parameters of the octahedral complex. Thus, we only used $\mathrm{Cu}$ octahedron in our following geometric analysis. The ligand bond to $\mathrm{Cu}$ (II) octahedron could be $\mathrm{O}, \mathrm{OH}$, or $\mathrm{H}_{2} \mathrm{O}$, and we will use $\mathrm{O}$ throughout this paper to represent these possible ligands. The equatorial oxygen-oxygen $(\mathrm{O}-\mathrm{O})$ distances in a distorted $\mathrm{Cu}(\mathrm{II}) \mathrm{O}_{6}$ octahedron are approximately $2.80 \AA$ [45], and the $\mathrm{Cu}-\mathrm{O}$ distances of our adsorption samples are approximately $1.95 \AA$ (Table 1 ). The Mn-O distances of $\mathrm{MnO}_{6}$ in the biogenic $\mathrm{Mn}$ oxide are $2.095 \AA, 1.903 \AA, 2.178 \AA$ and $2.350 \AA$, respectively [31]. Based on these coordination distances and the geometry coordination model (Fig. 5), we analyzed the possible linkages between a $\mathrm{Cu}(\mathrm{II}) \mathrm{O}_{6}$ octahedron and a $\mathrm{MnO}_{6}$ octahedron as follows:
(1) $\mathrm{A} \mathrm{Cu}(\mathrm{II}) \mathrm{O}_{6}$ octahedron and one $\mathrm{MnO}_{6}$ octahedron can link as a monodentate mononuclear (MM) complex (Fig. 5a). This structure could exhibit $\mathrm{Cu}-\mathrm{Mn}$ distances in the range of approximately $2.800-4.300 \AA$. The range of $\mathrm{Cu}-\mathrm{Mn}$ distances is large because $\mathrm{Cu}$ can be coordinated by either equatorial or axial oxygen. Furthermore, it is theoretically possible that a $\mathrm{Cu}(\mathrm{II}) \mathrm{O}_{6}$ octahedron and a $\mathrm{MnO}_{6}$ octahedron could link at a flexible angle. The $\mathrm{Cu}-\mathrm{Mn}$ distances observed in the two samples (Table 1) are all within the indicated range, suggesting that $\mathrm{MM}$ is the first likely linkage.

(2) $\mathrm{A} \mathrm{Cu}(\mathrm{II}) \mathrm{O}_{6}$ octahedron and one $\mathrm{MnO}_{6}$ octahedron can link as a bidentate mononuclear (BM) complex (Fig. 5b). The $\mathrm{Cu}-\mathrm{Mn}$ distance in this edge-sharing mode is approximately $2.80 \AA$, which is much shorter than the $\mathrm{Cu}-\mathrm{Mn}$ distances in the two samples $(3.37 \AA$, $3.44 \AA$ A), implying that the possibility of a face-sharing and an edge-sharing linkage can be excluded.

(3) $\mathrm{A} \mathrm{Cu}(\mathrm{II}) \mathrm{O}_{6}$ octahedron and two adjacent $\mathrm{MnO}_{6}$ octahedra can link as a bidentate binuclear (BB)
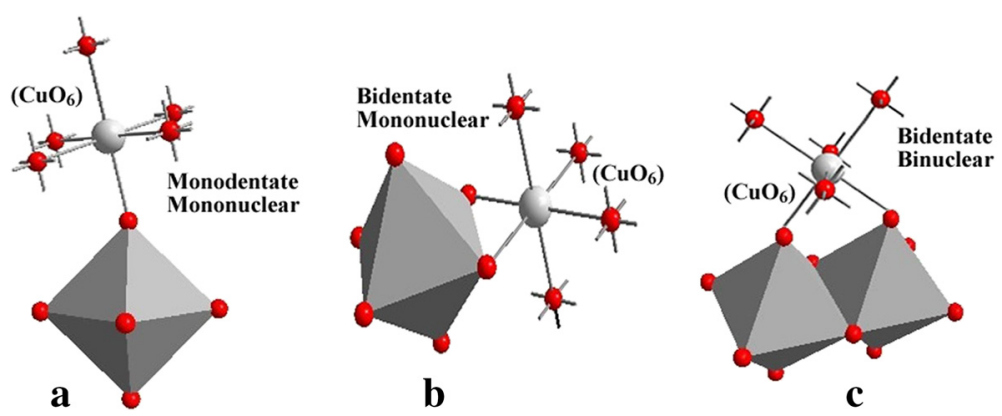

Fig. 5 Three types of linkage between sorbed $\mathrm{Cu}^{2+}\left(\mathrm{CuO}_{6}\right.$ octahedron) and the $\mathrm{MnO}_{6}$ octahedron on the surface of biogenic $\mathrm{Mn}$ oxide: (a) monodentate mononuclear $(M M)$; (b) bidentate mononuclear $(B M)$; (c) bidentate binuclear (BB) 
complex (Fig. 5c). Based on a spatial geometry, the theoretical $\mathrm{Cu}-\mathrm{Mn}$ distance for this BB linkage can be calculated using the following trigonometric function:

$$
\begin{aligned}
d(\mathrm{Cu}-\mathrm{Mn})^{2}= & d(\mathrm{Cu}-\mathrm{O})^{2}+d(\mathrm{Mn}-\mathrm{O})^{2}-2 d(\mathrm{Cu}-\mathrm{O}) \\
& \times d(\mathrm{Mn}-\mathrm{O}) \times \cos (\theta)
\end{aligned}
$$

where $d$ is the atomic distance of the indicated interatomic bond, and $\theta$ is the $\mathrm{Mn}-\mathrm{O}-\mathrm{Cu}$ angle. The $\mathrm{Cu}-\mathrm{Mn}$ distance in this mode is approximately in the range of 2.73 to $3.98 \AA$ (Additional file $1: \mathrm{S} 1$ ). The $\mathrm{Cu}-\mathrm{Mn}$ distances of the two samples (Table 1) are all within the indicated range, implying that $\mathrm{BB}$ is the second likely linkage. However, the coordination number of the sample pH6.0-Cu4.0 is $0.7(0.3)$, which is far less than the theoretical coordination number $(C N=2)$ of $\mathrm{BB}$ mode, indicating that the possibility of a bidentate binuclear (BB) complex in the sample pH6.0-Cu4.0 can be rejected.

Therefore, at a low $\mathrm{Cu}^{2+}$ loading, the sorbed $\mathrm{Cu}^{2+}$ could link with the $\mathrm{MnO}_{6}$ octahedra with two types of complexes: (1) one $\mathrm{CuO}_{6}$ octahedron and one $\mathrm{MnO}_{6}$ octahedron (regular or distorted) linked as MM (Fig. 6a); (2) one $\mathrm{CuO}_{6}$ octahedron and two adjacent $\mathrm{MnO}_{6}$ octahedra linked as BB (Fig. 6b). At a high $\mathrm{Cu}^{2+}$ loading, $\mathrm{Cu}^{2+}$ $\left(\mathrm{CuO}_{6}\right)$ could link with $\mathrm{MnO}_{6}$ octahedra only in one possible type of complex, one $\mathrm{CuO}_{6}$ octahedron and one $\mathrm{MnO}_{6}$ octahedron (regular or distorted) linked as $\mathrm{MM}$ (Fig. 6a). There is a little difference in the coordination mode between the low and high $\mathrm{Cu}^{2+}$ loading samples, probably because there are still some adsorption sites in the low $\mathrm{Cu}^{2+}$ loading sample $(233 \mathrm{mmol} / \mathrm{kg})$, resulting in the shift of some sorbed $\mathrm{Cu}^{2+}$ in the monodentate mononuclear (MM) complex to the bidentate binuclear (BB) complex, a more stable geometric structure. However, in the high $\mathrm{Cu}^{2+}$ loading sample $(787 \mathrm{mmol} / \mathrm{kg})$, there is almost no additional adsorption site in it, because the adsorption density $(787 \mathrm{mmol} / \mathrm{kg})$ is almost in the maximum adsorption capacity $(796 \mathrm{mmol} / \mathrm{kg}$ ) of the biogenic $\mathrm{Mn}$ oxide.

It should be noted that, in all of the above analyses, mainly the bulk structure of the biogenic Mn oxide (bixbyite) was considered, implying that the bulk and the surface structure of the biogenic Mn oxide were assumed to be the same. When the surface structure becomes available, the options for the $\mathrm{Cu}^{2+}$ complex structures on the surface of the biogenic bixbyite-like phase might be further constrained. The aforementioned results could provide a good reference for understanding the interactions between metal cations and biogenic or abiogenic lowvalence Mn oxides, which are still poorly explored both theoretically and experimentally.

\section{Experimental}

\section{Biogenic Mn oxide}

The biogenic Mn oxide was reported in our previous work [31]. Briefly, biogenic Mn oxides were produced by culturing an isolated Mn-oxidizing bacterium using Leptothrix discophora medium with initial $\mathrm{Mn}$ (II) concentration at $1.0 \mathrm{mM}$. The biogenic $\mathrm{Mn}$ oxide was harvested after 12 days via centrifugation at $10,000 \mathrm{RCF}\left(25^{\circ} \mathrm{C}, 5 \mathrm{~min}\right)$, because at which time the Mn-oxide concentration was at its maximum. The biogenic Mn oxide used in this study is a poorly-crystalline bixbyite (JCPDS 01-078-0390), with a bulk-averaged $\mathrm{Mn}$ oxidation state (AOS) of 2.73. It is

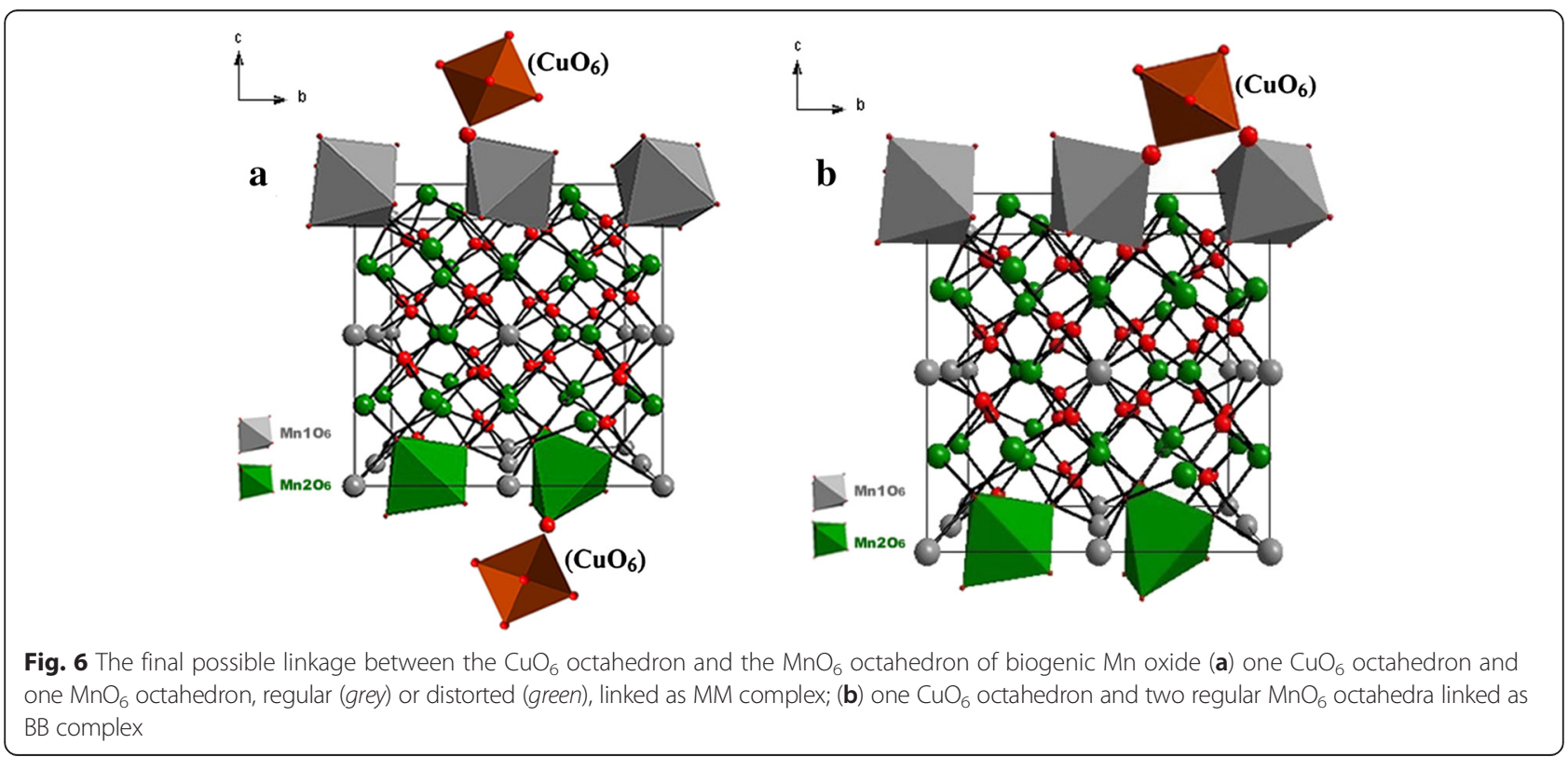


composed of uniform aggregates of granular particles with sizes of $25-50 \mathrm{~nm}$, and a specific surface area of $49 \mathrm{~m}^{2} / \mathrm{g}$ [31].

Bixbyite is a cubic, granular manganese oxide mineral of the cubic crystal system Ia-3 (SG.NO.206) with regular and distorted $\mathrm{MnO}_{6}$ octahedra alternately arranged in the structure $[48,31]$. In the structure of crystalline bixbyite, the cations occupy the $8 a$ site at 0,0 , 0 , etc. and the $24 d$ site at $\mathrm{x}, 0,0.25$, etc., with $\mathrm{x}=0.2855$ [48]. The anions occupy the general 48 e site, $\mathrm{x}, \mathrm{y}, \mathrm{z}(0.1293$, $0.1471,-0.0835)$, whereas the $16 c$ site, $x, x, x$, is unoccupied, being the site of the "anion vacancies", with $\mathrm{x}=$ 0.125. The cell formula is $\mathrm{Mn}_{32} \mathrm{O}_{48} \square_{16}$ ( $\square$ denotes an anion vacancy) [48]. In the ideal structure of bixbyite, the $\mathrm{Mn} 1$ atoms of the $8 a$ site are incorporated into the regular $\mathrm{Mn} 1 \mathrm{O}_{6}$ octahedra and the $\mathrm{Mn} 2$ atoms of the

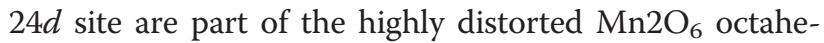
dra/polyhedron due to the distortion of the $3 \mathrm{~d}^{4} \mathrm{Mn}(\mathrm{III})$ ions. The six $\mathrm{Mn}-\mathrm{O}$ distances of the regular $\mathrm{Mn} \mathrm{O}_{6}$ octahedra in the prepared biogenic Mn oxide of this study are $2.095 \AA$, while the $\mathrm{Mn}$-O distances in the distorted ${\mathrm{Mn} 2 \mathrm{O}_{6}}_{6}$ octahedra have three different pairs at $1.903 \AA, 2.178 \AA$ and $2.350 \AA$ [31].

\section{Sorption of $\mathrm{Cu}^{2+}$ on biogenic Mn Oxide}

Sorption experiments of $\mathrm{Cu}^{2+}$ on the biogenic $\mathrm{Mn}$ oxides were carried out as previously reported by Zhao et al. [49] and Zhang et al. [31]. Briefly, $5.0 \mathrm{~g} / \mathrm{L}$ mineral suspensions were prepared and equilibrated for a few days, during which the $\mathrm{pH}$ was adjusted to $6.00( \pm 0.05)$ with $0.1 \mathrm{M} \mathrm{HNO}_{3}$ or $0.1 \mathrm{M} \mathrm{NaOH}$. Sorption experiments were initiated by adding $20 \mathrm{~mL}$ of the final suspension to a $100-\mathrm{mL}$ polypropylene bottle containing $0.8 \mathrm{~mL}$ to $16 \mathrm{~mL}$ of $15-\mathrm{mM} \mathrm{Cu}\left(\mathrm{NO}_{3}\right)_{2}$ solution. The total volume of the solution in each bottle was increased to $60 \mathrm{~mL}$ by adding $0.15 \mathrm{M} \mathrm{NaNO}_{3}$. Therefore, the sorbent concentration was $1.67 \mathrm{~g} / \mathrm{L}$, the ionic strength was approximately $0.1 \mathrm{M}$ and the $\mathrm{Cu}^{2+}$ initial concentrations were 0.2 to $4.0 \mathrm{mM}$, respectively. The polypropylene bottles with suspensions were immediately capped and shaken, and the $\mathrm{pH}$ was adjusted twice during the equilibration period to $6.00( \pm 0.05)$. After $24 \mathrm{~h}$ of equilibration, the suspensions were centrifuged. Approximately $10 \mathrm{~mL}$ of the clear supernatant liquid was used for the determination of the $\mathrm{Cu}^{2+}$ concentration using a Varian AAS 240FS atomic absorption spectrometer (USA). The precipitates were collected and conserved at $4{ }^{\circ} \mathrm{C}$ for the XAS analysis.

\section{XAS data collection}

The XAS spectra of all of the samples were collected on the 1W1B beamline at Beijing Synchrotron Radiation Facility (BSRF) [31, 50-52]. Cu sorption samples were obtained from centrifugation and prepared by the procedures of
Zhang et al. [31]. The EXAFS spectra $(8979 \mathrm{eV})$ were collected with a Lytle ion-chamber detector in fluorescence mode. The reference compounds, solid $\mathrm{Cu}(\mathrm{OH})_{2}$ powder, copper acetate monohydrate and copper aqueous solutions $\left(0.1 \mathrm{M} \mathrm{Cu}\left(\mathrm{NO}_{3}\right)_{2}\right)$ were measured in transmission mode. The energy was calibrated with $\mathrm{Cu}$ foil. Reduction and analysis of all XAS data were performed using IFEFFIT/ SIXPACK [53]. The $\mathrm{Cu} \mathrm{K-edge} \mathrm{averaged} \mathrm{spectra} \mathrm{were}$ background-subtracted using the following parameters: $E_{0}=8979 \mathrm{eV}, R b k g=1.0 \AA$ and $k$-weight $=3$. Phase and amplitude functions for single-scattering paths were calculated using FEFF7 [54]. An amplitude reduction factor $\left(\mathrm{S}_{0}^{2}\right)$ of 0.96 was determined by fitting the $\mathrm{Cu}-\mathrm{O}$ shell of $\mathrm{Cu}\left(\mathrm{NO}_{3}\right)_{2}(\mathrm{aq})$ spectra in the $R$-range 1.0-2.0 $\AA$, and the other samples were fitted with $S_{0}^{2}$ fixed at 0.96 . The calculations of the phase shift and amplitude functions of $\mathrm{Cu}-\mathrm{Mn}$ were based on the crystal structure of $\mathrm{CuMnO}_{2}$ (Crednerite). Final fits of the two sorption samples were made in Artemis in $R$-range 1.0-3.8 $\AA$.

\section{Conclusions}

In this study, a low valence biogenic Mn oxide, a poorly crystallized bixbyite-like $\mathrm{Mn}_{2} \mathrm{O}_{3}\left(\alpha-\mathrm{Mn}_{2} \mathrm{O}_{3}\right)$, which has barely been studied in the past several decades, was used as an adsorbent and the adsorption mechanisms of $\mathrm{Cu}$ (II) on it were studied. The maximum adsorption capacity of $\mathrm{Cu}$ (II) adsorbed to the biogenic Mn oxide at $\mathrm{pH} 6.00$ was $796 \mathrm{mmol} / \mathrm{kg}$, indicating that the biogenic Mn oxide could be an promising adsorbent for eliminating $\mathrm{Cu}(\mathrm{II})$ from soil and water environments. At a relatively low $\mathrm{Cu}(\mathrm{II})$ loading $(233 \mathrm{mmol} / \mathrm{kg}$ ) sample, $\mathrm{Cu}(\mathrm{II})$ was adsorbed onto the biogenic $\mathrm{Mn}$ oxide as innersphere complexes and linked with $\mathrm{MnO}_{6}$ octahedra by two types of complexes: $\mathrm{MM}$ and $\mathrm{BB}$. At a relatively high $\mathrm{Cu}(\mathrm{II})$ loading $(787 \mathrm{mmol} / \mathrm{kg})$, the adsorbed $\mathrm{Cu}(\mathrm{II})$ linked with $\mathrm{MnO}_{6}$ octahedra only by $\mathrm{MM}$ type of complex. These results provide further insight into the bacterial $\mathrm{Mn}(\mathrm{II})$ oxidation in the environment and a good reference for understanding the biogeochemistry of low valence of biogenic $\mathrm{Mn}$ oxides and their interactions with metal ions in the natural environments, which are still poorly explored, either theoretically or practically. Furthermore, this research could also enrich or contribute a new understanding of the biogeochemical processes of $\mathrm{Mn}$ oxides and their environmental significance.

\section{Additional file}

Additional file 1: S1 Calculation of the possible Cu-Mn distance of BB.

The following additional data are available with the online version of this paper.

\section{Competing interests}

The authors declare that they have no competing interests. 


\section{Authors' contributions}

ZZ had the lead role in all stages of data acquisition, analyses and interpretation, and drafted this manuscript. JL participated in sorption experiment and helped to draft the manuscript. HY provided support in XANES data analyses and helped to draft the manuscript. XF and WT contributed to draft the manuscript. FL had the lead role in the design of the study, data analyses and interpretation and helped to draft the manuscript. All authors have given final approval of the manuscript version to be published.

\section{Acknowledgments}

We owe great thanks to Dr. Lirong Zheng, Dr. Jing Zhang and Dr. Shengqi Chu at beamline 1W1B at the Beijing Synchrotron Radiation Facility (BSRF) for the technical assistance with data collection and analysis. The authors gratefully thank the National Natural Science Foundation of China (Nos. 40830527 and 41271253 ) for financial support of this research.

\section{Author details}

${ }^{1}$ Key Laboratory of Arable Land Conservation (Middle and Lower Reaches of Yangtse River), Ministry of Agriculture, College of Resources and Environment, Huazhong Agricultural University, Wuhan 430070, China. ${ }^{2}$ CAS Key laboratory of Mineralogy and Metallogeny, Guangzhou Institute of Geochemistry, Chinese Academy of Sciences, Wushan, Guangzhou 510640, China.

Received: 29 January 2015 Accepted: 4 May 2015

Published online: 13 May 2015

\section{References}

1. Grimalt JO, Ferrer M, Macpherson E. The mine tailing accident in Aznalcollar. Sci Total Environ. 1999;242:3-11.

2. Younger $\mathrm{PH}$. Nature and practical implications of heterogeneities in the geochemistry of zinc-rich, alkaline mine waters in an underground F-Pb mine in the UK. Appl Geochem. 2000;15:762-9.

3. Rico A, Benito G, Diez-Herrero A. Floods from tailings dam failures. J Hazard Mater. 2008;154:79-87.

4. Zhuang P, McBride MG, Xia HP, Li NY, Lia ZA. Health risk from heavy metals via consumption of food crops in the vicinity of Dabaoshan mine, South China. Sci Toal Environ. 2009:407:1551-61.

5. Jacobson AR, Dousset S, Andreux F, Baveye PC. Electron microprobe and synchrotron $\mathrm{X}$-ray fluorescence mapping of the heterogeneous distribution of copper in high-copper vineyard soils. Environ Sci Technol. 2007;41:6343-9.

6. Strawn DG, Baker LL. Speciation of Cu in a contaminated agricultural soil measured by XAFS, $\mu$-XRF. Environ Sci Technol. 2008;42:37-42.

7. Hochella MF, Moore JN, Putnis CV, Putnis A, Kasama T, Eberl DD. Direct observation of heavy metal mineral association from the Clark Fork River superfund complex: implications for metal transport and bioavailability. Geochimica Et Cosmochimica Acta. 2005;69:1651-63.

8. Jenne EA. Controls on Mn Fe Co Ni Cu and $\mathrm{Zn}$ concentrations in soils and water: the significant role of hydrous $\mathrm{Mn}$ and Fe Oxides. In: Baker RA, editor. Trace inorganics in water. Vol. 73. Washington, DC: American Chemical Society; 1968. p. 337-87.

9. McLaren RG, Crawford DV. Studies on soil copper .II. Specific adsorption of copper by soils. J Soil Sci. 1973;24:443-52.

10. Davies-Colley RJ, Nelson PO, Williamson KJ. Copper and cadmium uptake by estuarine sedimentary phases. Environ Sci Technol. 1984;18:491-9.

11. Peña J, Bargar JR, Sposito G. Copper sorption by the edge surfaces of synthetic birnessite nanoparticles. Chem Geol. 2015;396:196-207.

12. Feng $X H$, Zhu MQ, Ginder-Vogel M, Ni CY, Parikh SJ, Sparks DL. Formation of nano-crystalline todorokite from biogenic Mn oxides. Geochimica Et Cosmochimica Acta. 1974;2010:3232-45.

13. Santelli CM, Webb SM, Dohnalkova AC, Hansel CM. Diversity of Mn oxides produced by Mn(II)-oxidizing fungi. Geochimica Et Cosmochimica Acta. 2011;75:2762-76.

14. Zhu MQ, Farrow CL, Post JE, Livi KJT, Billinge SJL, Ginder-Vogel M, et al. Structural study of biotic and abiotic poorly-crystalline manganese oxides using atomic pair distribution function analysis. Geochimica Et Cosmochimica Acta. 2012;81:39-55.

15. Mandernack KW, Post J, Tebo BM. Manganese mineral formation by bacterial spores of the marine Bacillus, strain SG-1: evidence for the direct oxidation of $\mathrm{Mn}(\mathrm{II})$ to $\mathrm{Mn}(\mathrm{IV})$. Geochimica Et Cosmochimica Acta. 1995;59:4393-408.
16. Tebo BM, Ghiorse WC, van Waasbergen LG, Siering PL, Caspi R. Bacterially mediated mineral formation: insights into manganese(II) oxidation from molecular genetic and biochemical studies. In: Banfield JF, Nealson KH, editors. Geomicrobiology: interactions between microbes and minerals. Reviews in mineralogy. Vol. 35. Washington, DC: Mineralogical Society of America Press; 1997. p. 225-66.

17. Caspi R, Tebo BM, Haygood MG. c-Type cytochromes and manganese oxidation in Pseudomonas putida MnB1. Appl Environ Microbiol. 1998;64:3549-55.

18. De Vrind JPM, Brouwers GJ, Corstjens PLAM, den Dulk J, de Vrind-de Jong $\mathrm{EW}$. The cytochrome $\mathrm{c}$ maturation operon is involved in manganese oxidation in Pseudomonas putida GB-1. Appl Environ Microbiol. 1998;64:3556-62.

19. Bargar JR, Tebo BM, Villinski JE. In situ characterization of Mn(II) oxidation by spores of the marine Bacillus sp. strain SG-1. Geochimica Et Cosmochimica Acta. 2000;64:2775-8.

20. Tebo BM, Bargar JR, Clement BG, Dick GJ, Murray KJ, Parker D, et al. Biogenic manganese oxides: properties and mechanisms of formation. Annu Rev Earth Planet Sci. 2004;32:287-328.

21. Tanaka K, Tani Y, Takahashi Y, Tanimizu M, Suzuki Y, Kozai N, et al. A specific Ce oxidation process during sorption of rare earth elements on biogenic $\mathrm{Mn}$ oxide produced by Acremonium sp. strain KR21-2. Geochimica Et Cosmochimica Acta. 2010;74:5463-77.

22. Peña J, Kwon KD, Refson K, Bargar JR, Sposito G. Mechanisms of nickel sorption by a bacteriogenic birnessite. Geochimica Et Cosmochimica Acta. 2010;74:3076-89.

23. Takano K, Itoh Y, Ogino T, Kurosawa K, Sasaki K. Phylogenetic analysis of manganese-oxidizing fungi isolated from manganese-rich aquatic environments in Hokkaido, Japan. Limnology. 2006;7:219-23.

24. Yu QQ, Sasaki K, Tanaka K, Ohnuki T, Hirajima T. Structural factors of biogenic birnessite produced by fungus Paraconiothyrium sp.WL-2 strain affecting sorption of $\mathrm{Co}^{2+}$. Chem Geol. 2012;310-311:106-13.

25. Nelson YM, Lion LW, Ghiorse WC, Shuler ML. Production of biogenic Mn oixdes by leptothrix descophora SS-1 in a chemically defined growth medium and evaluation of their $\mathrm{Pb}$ adsorption characteristics. Appl Environ Microbiol. 1999;65:175-80.

26. Villalobos M, Bargar J, Sposito G. Mechanisms of $\mathrm{Pb}(\mathrm{II})$ sorption on a biogenic manganese oxide. Environ Sci Technol. 2005;39:569-76.

27. Miyata N, Maruo K, Tani Y, Tsuno H, Seyama H, Soma M, et al. Production of biogenic manganese oxides by anamorphic Ascomycete fungi isolated from streambed pebbles. Geomicrobiol J. 2006;23:63-73.

28. Zhu MQ, Ginder-Vogel M, Parikh SJ, Feng XH, Sparks DL. Cation effects on the layer structure of biogenic Mn-Oxides. Environ Sci Technol. 2010;44:4465-71.

29. Learman DR, Voelker BM, Vazquez-Rodriguez Al, Hansel CM. Formation of manganese oxides by bacterially generated superoxide. Nature Geo. 2011:4:95-8

30. Hosseinkhani B, Emtiati G. Synthesis and characterization of a novel extracellular biogenic manganese oxide (bixbyite-like $\mathrm{Mn}_{2} \mathrm{O}_{3}$ ) nanoparticle by isolated acinetobacter sp. Curr Microbiol. 2011;63:300-5.

31. Zhang ZJ, Yin H, Tan WF, Koopal LK, Zheng LR, Feng XH, et al. Zn sorption to biogenic bixbyite-like $\mathrm{Mn}_{2} \mathrm{O}_{3}$ produced by Bacillus CUA isolated from soil: XAFS study with constraints on sorption mechanism. Chem Geol. 2014:389:82-90.

32. Webb SM, Dick GJ, Bargar JR, Tebo BM. Evidence of the presence of Mn(III) intermediates in the bacterial oxidation of Mn(II). Proc Natl Acad Sci U S A 2005;102:5558-63.

33. Traina SJ, Doner HE. Copper manganese(II) exchange on a chemically reduced birnessite. J Soil Sci Soc Am. 1985:49:307-13.

34. Karthikeyan KG, Elliott HA, Chorover J. Role of surface precipitation in copper sorption by the hydrous oxides of iron and aluminum. J Colloid Interface Sci. 1999;209:72-8

35. Manceau A, Lanson B, Drits VA. Structure of heavy metal sorbed birnessite. Part III: results from powder and polarized extended X-ray absorption fine structure spectroscopy. Geochimica Et Cosmochimica Acta. 2002;66:2639-63.

36. Sherman DM, Peacock CL. Surface complexation of Cu on birnessite (delta-MnO2): controls on Cu in the deep ocean. Geochimica Et Cosmochimica Acta. 2010;74:6721-30.

37. Arai $Y$. Aqueous interfacial chemistry of kaolinite for the removal of $\mathrm{Cu}(\mathrm{II})$ in the presence of birnessite: kinetic and spectroscopic studies. Appl Clay Sci. 2011;53:572-80. 
38. Wang $Y$, Feng $X H$, Villalobos M, Tan WF, Liu F. Sorption behavior of heavy metals on birnessite: relationship with its $\mathrm{Mn}$ average oxidation state and implications for types of sorption sites. Chem Geol. 2012;292:25-34.

39. Kwon KD, Refson K, Sposito G. Understanding the trends in transition metal sorption by vacancy sites in birnessite. Geochimica Et Cosmochimica Acta. 2013;101:222-32

40. Pasquarello A, Petri I, Salmon PS, Parisel O, Car R, Tóth E, et al. First solvation shell fo the $\mathrm{Cu}(\mathrm{II})$ aqua ion: evidence for fivefold coordination. Science. 2001;291:856-9.

41. Frank P, Benfatto M, Szilagyi RK, D'Angelo P, Della Longa S, Hodgson KO. The solution structure of $[\mathrm{Cu}(\mathrm{aq})]^{2+}$ and its implications from rack-induced bonding in blue copper protein active. Inorg Chem. 2005;44:1922-33.

42. Bryantsev VS, Diallo MS, van Duin ACT, Goddard III WA. Hydration of copper(II): New insights from density functional theory and the COSMO solvation model. J Phys Chem. 2008;A112:9104-12.

43. Shimizu K, Maeshima H, Yoshida H, Satsuma A, Hattori T. Ligand field effect on the chemical shift in XANES spectra of Cu(II) compounds. Phys Chem Chem Phys. 2001;3:862-6.

44. Dupont L, Guillon E, Bouanda J, Dumonceau J, Aplincourt M. EXAFS and XANES studies of retention of copper and lead by a lignocellulosic biomaterial. Environ Sci Technol. 2002;36:5062-6.

45. Cheah SF, Brown GE, Parks GA. XSFS spectroscopy study of $\mathrm{Cu}(\mathrm{II})$ sorption on amorphous $\mathrm{SiO}_{2}$ and $\gamma-\mathrm{Al}_{2} \mathrm{O}_{3}$ : effect of substrate and time on sorption complexes. J Colloid Interface Sci. 1998;208:110-28.

46. Cheah SF, Brown GE, Parks GA. XAFS study of Cu model compounds and $\mathrm{Cu}^{2+}$ sorption products on amorphous $\mathrm{SiO} 2$, gamma- $\mathrm{Al}_{2} \mathrm{O}_{3}$, and anatase. Am Mineral. 2000;85:118-32.

47. Manceau A, Lanson M, Geoffroy N. Natural speciation of Ni, Zn, Ba, and As in ferromanganese coatings on quartz using $\mathrm{X}$-ray fluorescence, absorption, and diffraction. Geochimica Et Cosmochimica Acta. 2007;71:95-128.

48. Bevan DJM, Martin RL. The role of the coordination defect: a new structural description of four fluorite-related sesquioxide minerals, bixbyite $\left(\mathrm{Mn}_{2} \mathrm{O}_{3}\right)$, braunite $\left(\mathrm{Mn}_{7} \mathrm{SiO}_{12}\right)$, braunite $\left(\mathrm{CaMn}_{14} \mathrm{SiO}_{24}\right)$, parwelite $\left(\mathrm{Mn}_{10} \mathrm{Sb}_{2} \mathrm{As}_{2} \mathrm{Si}_{2} \mathrm{O}_{24}\right)$, and their structural relationships. J Solid State Chem. 2000;181:2250-9.

49. Zhao W, Cui HJ, Liu F, Tan WF, Feng XH. Relationship between $\mathrm{Pb}^{2+}$ adsorption and average $\mathrm{Mn}$ oxidation state in synthetic birnessites. Clays Clay Miner. 2009;57:513-20.

50. Yin H, Tan WF, Zheng LR, Cui HJ, Qiu GH, Liu F, et al. Characterization of $\mathrm{Ni}$-rich hexagonal birnessite and its geochemical effects on aqueous $\mathrm{Pb}^{2}$ ${ }^{+} / \mathrm{Zn}^{2+}$ and As(III). Geochimica Et Cosmochimica Acta. 2012;93:47-62.

51. Yin H, Liu F, Feng XH, Hu TD, Zheng LR, Qiu GH, et al. Effects of Fe doping on the structures and properties of hexagonal birnessites-Comparison with Co and Ni doping. Geochimica Et Cosmochimica Acta. 2013;117:1-15.

52. Yin H, Li H, Wang Y, Ginder-Vogel M, Qiu GH, Feng XH, et al. Effects of Co and $\mathrm{Ni}$ co-doping on the structure and reactivity of hexagonal birnessite. Chem Geol. 2014;381:10-20.

53. Webb SM. SIXpack: a graphical user interface for XAS analysis using IFEFFIT. Phys Scr. 2005;T115:1011-4.

54. Rhehr JJ, Zabinsky SI, Albers RC. High-order multiple scattering calculations of X-ray-absorption fine structure. Phys Rev Lett. 1992;29:1898-905.

Publish with ChemistryCentral and every
scientist can read your work free of charge
"Open access provides opportunities to our
colleagues in other parts of the globe, by allowing
anyone to view the content free of charge."
W. Jeffery Hurst, The Hershey Company.
- available free of charge to the entire scientific community
- peer reviewed and published immediately upon acceptance
- cited in PubMed and archived on PubMed Central
- yours - you keep the copyright
submit your manuscript here:
http://www.chemistrycentral.com/manuscript/

